\title{
Hydrological Changes in the White Sea during the Historical Period Inferred from Analysis of Dinocysts
}

\author{
E. A. Novichkova ${ }^{a}$ and E. I. Polyakova ${ }^{b}$ \\ Presented by Academician A.P. Lisitsyn August 8, 2007
}

Received August 8, 2007

DOI: $10.1134 / \mathrm{S} 1028334 X 08080242$

According to available historical evidence, colonization of the White Sea region began in the 9th-8th centuries B.C. [2]. This unique region with ancient residence sites experiences progressively increasing anthropogenic load against the background of natural climatic changes. The intense economic development of the region requires complex ecological and paleogeographic studies aimed at detailed reconstruction of past sedimentation settings.

The analysis of dinocysts, which makes it possible to reconstruct various parameters of water masses washing the Arctic shelf, has become a promising method in paleohydrological studies, widely used in recent years [10,11]. Dinoflagellates, which represent one of the main phytoplankton groups in the Arctic Seas, the White Sea included, form cysts with biopolymer envelopes, which are preserved in sediments. Thus, information on glacial-hydrological conditions is recorded in marine sediments. In the White Sea, this method was first used for the study of bottom sediments only in 2003 [3, 15].

In this communication, we present the first results obtained during the thorough study of dinocysts in bottom sediment cores from the White Sea, which cover the last 250 years. The study of this microfossil group made it possible to reconstruct in detail changes in glacial-hydrological settings in the sea and reveal their relations with known climatic-hydrological events that occurred in neighboring regions during the historical period.

\section{MATERIALS AND METHODS}

Examined cores 4719 and 4706 were sampled by the Neimisto corer with an inner diameter of $53 \mathrm{~mm}$ during

\footnotetext{
a Shirshov Institute of Oceanology, Russian Academy of Sciences, Nakhimovskii pr. 36, Moscow, 117997 Russia

${ }^{b}$ Geography Department, Moscow State University, Moscow Russia
}

Cruise 49 of the R/V Professor Shtokman (August 2001) by scientists from the Laboratory of PhysicalGeological Studies of the Institute of Oceanology, Russian Academy of Sciences. Cores 68 and $20 \mathrm{~cm}$ long were taken in the open part of the Kandalaksha and Onezhskii bays at water depths of 277.0 and $65.6 \mathrm{~m}$, respectively (Fig. 1a). According to ${ }^{210} \mathrm{~Pb}$ and ${ }^{137} \mathrm{Cs}$ dating, their maximal age is 250 years [1]. The age of separate intervals is estimated based on calculated average sedimentation rates in this sea area: $2.2 \mathrm{~mm} /$ year under continuous sedimentation [1].

The sediment samples taken with a step of 1-4 cm for the dinocyst analysis were treated in line with the procedure used at the A. Wegener Institute in Potsdam [9]. For determining concentrations of dinocysts, a tablet with a fixed quantity of Lycopodium clavatum spores was added into the preliminarily weighted sample at its initial treatment stage [9]. Microfossils were studied under the light microscope Zeiss Axiostar+ with magnification of 400. At least 100 cysts were identified in each sample. The defined correlations of the composition of dinocyst assemblages and their distribution in bottom sediments of the White Sea with the main hydrological parameters of the sea photic layer served as a methodological base for paleoreconstructions [9].

\section{RESULTS}

The dinocyst assemblage in the examined cores numbers 12 species and their groups (table) characteristic also of surface waters in the present-day White Sea $[3,9,15]$. The sum concentrations of dinocysts range from 500 to 85000 cysts/g varying usually from 2000 to 3000 cysts/g of sediment (Fig. 1b). Their maximal contents are registered for the upper part of Core 4719 from Kandalaksha Bay corresponding to the period of 1980 to 2000.

For paleohydrological reconstructions, the identified species of dinocysts were divided into two main ecological groups (autotrophic and heterotrophic) in accordance with published data on the geographic dis- 


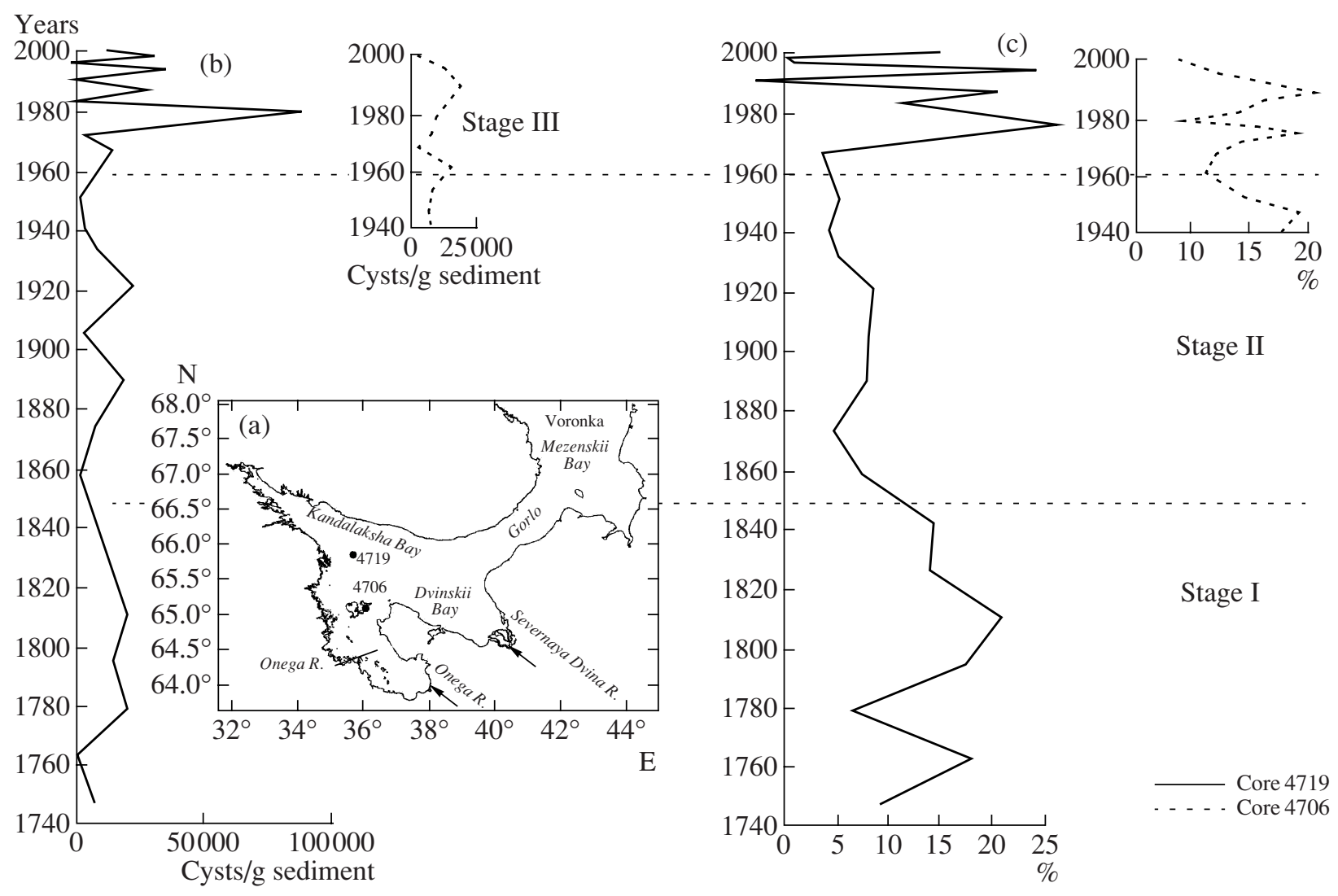

Fig. 1. The distribution of dinocysts in bottom sediment cores 4719 and 4706 from the White Sea and stages (I, II, and III) in glacialhydrological development during the last 250 years: (a) location of examined cores; (b) changes in concentrations of dinocysts in cores; (c) changes in proportions of heterotrophic relatively cold-resistant dinoflagellate species in cores.

tribution of these species and their ecological tolerance [12] as well as with results of our previous studies in the White Sea (table, [9]). The autotrophic community consisting of five species is dominated by Operculodinium centrocarpum, which prevails also in Recent sediments of the White Sea [9]. In examined open areas of Kandalaksha and Onezhskii bays, its content varies from 70 to $95 \%$, which is determined by minimal $(0.2-0.5 \mathrm{mg} / \mathrm{l})$ concentrations of suspended matter in waters and, correspondingly, favorable conditions for photosynthesis [9]. The occurrence of this species in dinocyst assemblages of the Arctic seas [7] is thought to be related to the distribution of warm Atlantic waters $[10,13]$. In the examined cores, dinocysts of autotrophic species dominate and their integral share ranges from 75 to $95 \%$.

The group of heterotrophic dinocysts is represented in both Recent and older examined sediments by species prevalent in the Arctic shelf seas (Islandinium minutum and close morphotypes I. cezare, Echinidinium karaense), which indicate significant duration of the ice cover (over six months annually) $[10,13]$. In the present-day White Sea, the maximal content of heterotrophic dinoflagellate species (up to 47\%) is distinctly confined to end areas of shallow bays with high turbidity of waters that are strongly influenced by the Onega and Severnaya Dvina river discharge $[9,15]$.

The total content of heterotrophic species in both cores varies from 2 to $25 \%$ reaching maximal concentrations in the periods from 1760 to 1850 and from 1960 to 2000 (Fig. 1c).

The examined cores of bottom sediments were obtained from the open areas of the Kamdalakshskii and Onezhskii bays, where the influence of the river runoff is now insignificant [14]. Such a situation was also characteristic of the last 250 years. This is evident from practically complete lack of freshwater green algae in sediments, which reflect river runoff in the Arctic shelf seas [12]. The present-day hydrological situation in study areas is determined by the distribution of seasonally stratified White Sea waters with a low content of suspended matter [7, 14]. The average annual duration of the seasonal ice cover is approximately 6.5 months [8].

Based on established changes in the distribution of defined ecological groups of dinocysts and their abundances in sediments of the examined cores (4719 and 4706), three main stages are distinguished in development of glacial-hydrological conditions in the White 
Composition of dinoflagellate cysts in sediments of cores 4719 and 4706 (White Sea), planktonic stages of cysts, and their ecological affinity

\begin{tabular}{|c|c|c|c|}
\hline Planktonic stage of dinoflagellates & Dinocysts & $\begin{array}{l}\text { Autotrophic } \\
\text { species }\end{array}$ & $\begin{array}{l}\text { Heterotrophic } \\
\text { species }\end{array}$ \\
\hline Gonualax digitalis (Pouchet) Kofoid & Bitectatodinium tepikiense Wilson & + & \\
\hline $\begin{array}{l}\text { Protoperidinium cf. avellanum (Meunier) } \\
\text { Balech }\end{array}$ & Brigantedinium cariacoense (Wall). Reid & & + \\
\hline Protoperidinium conicoides (Paulsen) Balech & Brigantedinium simplex (Wall). Reid & & + \\
\hline Protoperidiniaceae & $\begin{array}{l}\text { Echinidinium karaense Head, } \\
\text { Harland \& Matthiessen }\end{array}$ & & + \\
\hline Protoperidiniaceae & Islandinium minutum Harland \& Reid & & + \\
\hline Protoperidiniaceae & Islandinium? cezare de Vernal et al & & + \\
\hline $\begin{array}{l}\text { Protoceratium reticulatum } \\
\text { (Claparende \& Lachmann) Diesing }\end{array}$ & Operculodinium centrocarpum Wall \& Dale 1966 & + & \\
\hline Scrippsiella faeroense (Stein) Balech & $\begin{array}{l}\text { Cysts of Pentapharsodinium dalei Indelicato } \\
\& \text { Loeblich }\end{array}$ & + & \\
\hline Polykrikos sp. Kunz-Pirrung & $\begin{array}{l}\text { Cysts of Polykrikos sp. Arctic morphotype } \\
\text { Kunz-Pirrung }\end{array}$ & & \\
\hline Protoperidinium conicum (Gran) Balech & Selenopemphix quanta (Bradford) Matsuoka & & + \\
\hline Gonualax elongata (Reid) Ellegaard & Spiniferites elongatus Reid & + & \\
\hline $\begin{array}{l}\text { Gonualax spinifera } \\
\text { (Claparende \& Lachmann) Diesing }\end{array}$ & Spiniferites ramosus Mantell & + & \\
\hline
\end{tabular}

Sea during the last 250 years: 1740 to 1850 (I), 1850 to 1960 (II), and 1960 to 2000 (III).

I. The period of 1740 to 1850 (Core 4719, Solovetskie Islands, Fig. 1a) was characterized by a high share of polar and subpolar heterotrophic dinoflagellate species of the genus Protoperidinium (up to $23 \%$, Fig. 1c) among dinocyst assemblages. This value exceeds significantly that in bottom sediments of the region, which indicates longer duration of the seasonal ice cover as compared with the present-day one. This period corresponds to the second half of the Little Ice Age that lasted in high latitudes of the Northern Hemisphere approximately from 1430 to $1850[4,5]$. This entire epoch was marked by an increased distribution area of Arctic marine ice and from 1780 to 1820 the average annual air temperature over the North Atlantic (north of $50^{\circ} \mathrm{N}$ ) being $1-3^{\circ} \mathrm{C}$ lower as compared to the present-day one $[4,5]$.

II. The subsequent stage of 1850 to 1960 was characterized by significant reduction of the seasonal ice cover, which is evident from the minimal (for the section of Core 4719) proportion of cold-water heterotrophic dinoflagellate species in their assemblages (Fig. 1c), which was lower as compared with the present-day one. The significant increase in the share of autotrophic species, primarily Operculodinium centrocarpum indicating the influx of Atlantic waters to the Arctic Ocean, might be explained by its increased vegetation period and growth of summer water temperatures.
In western Arctic seas and subarctic areas of the North Atlantic, the period under consideration was characterized by an unstable ice cover: Iceland waters were practically free of ice for 15 years after termination of the Little Ice Age $[4,5]$.

III. The period from 1960 until the present in the examined cores from the White Sea is marked by an increased share of cold-resistant heterotrophic dinoflagellate species in their assemblages (Fig. 1c). Significant repeated changes in both relative proportions of these species and abundance of dinocysts in sediments were likely determined by short-period climatic oscillations and fluctuations in glacial-hydrological conditions, which were established also in the neighboring Arctic area during the last decades of the last century $[4,5]$.

Thus, the analysis of the distribution of dinocysts in cores of bottom sediments from central areas of the White Sea reveals significant changes in glacial-hydrological conditions during the last 250 years. The defined stages in glacial-hydrological development of the sea (Figs. 1b, 1c) are generally synchronous with the known climatic and glacial-hydrological events in adjacent areas of the western Arctic and North Atlantic regions, which indicates the high potential of dinoflagellate analysis for study of the White Sea history.

\section{ACKNOWLEDGMENTS}

We are grateful to Academician A.P. Lisitsyn and V.P. Shevchenko for donated materials for this study 
and help in preparing the results for publication. We thank R.A. Aliev, an employee of the Research Institute of Nuclear Physics of Moscow State University for determination of sedimentation rates at sampling sites using the ${ }^{210} \mathrm{~Pb}$ and ${ }^{137} \mathrm{Cs}$ method and calculations of the presumed age of sediments. We are grateful also to the crew of the R/V Professor Shtokman and V.N. Churun, a worker of the Shmidt Laboratory (Arctic and Antarctic Research Institute, St. Petersburg) for vacuum drying of samples. This work was supported by the Russian Foundation for Basic Research (project nos. 0605-65267 and 06-05-64815), grant NSh-2236.2006.5, Project No. 4.4 of Program No. 17 of Basic Research (Presidium of the Russian Academy of Sciences), grant OSL-06-16, Project "Nanoparticles in Outer and Inner Spheres of the Earth" of the Earth Sciences Branch of the Russian Academy of Sciences.

\section{REFERENCES}

1. R. A. Aliev, V. A. Bobrov, S. N. Kalmykov, et al., Radiochemistry 48, 620 (2006) [Radiokhimiya 48, 557 (2006).

2. V. Ya. Berger and A. D. Naumov, in The White Sea. Biological Resources and Problems of Their Effective Usage (Zool. Inst. RAN, St. Petersburg, 1955), pt. 1, pp.7-40 [in Russian].

3. E. A. Golovnina and E. I. Polyakova, Doklady Earth Sciences 400, 136 (2005) [Dokl. Akad. Nauk 400, 382 (2005)\}.
4. J. Gribbin and H. H. Lamb, Climatic Changes (Gidrometeoizdat, Leningrad, 1980).

5. V. F. Zakharov, Ices of the Arctic Region and Recent Natural Resources (Gidrometeoizdat, Leningrad, 1981) [in Russian].

6. L. V. Il'ina, L. S. Zhitina, and V. D. Fedorov, Phytoplankton of the White Sea (Yanus-K, Moscow, 2003) [in Russian].

7. A. P. Lisitsyn, V. P. Shevchenko, V. I. Burenkov, et al., in Topical Problems of Oceanolgy (Nauka, Moscow, 2003), pp. 554-605 [in Russian].

8. E. N. Nevesskii, V. S. Medvedev, and V. V. Kalinenko, The White Sea. Sedimentogenesis and Development History in the Holocene (Nauka, Moscow, 1977) [in Russian].

9. E. A, Novichkova and E. I. Polyakova, Oceanology 47, 660 (2007) [Okeanologiya 47 (5), ??? (2007)].

10. M. Kunz-Pirrung, J. Quatern. Sci. 16, 637 (2001).

11. F. Marret and K. Zonneveld, Rev. Palaeobot. and Palynol. 125, 1 (2003).

12. J. Matthiessen, A. De Vernal, M. Head, et al., Palaeont. Zeitschr. 79/1, 3 (2005).

13. P. J. Mudie, R. Harland, J. Matthiessen, et al., J. Quatern. Sci. 16, 595 (2001)

14. A. N. Pantyulin, Oceanology 43 (Suppl.), 1 (2003).

15. E. I. Polyakova, R. N. Dzhinoridze, T. S. Novichkova, et al., Oceanology 43 (Suppl.), 144 (2003). 